\title{
PENULISAN PUISI BERTEMA LOKAL BUDAYA DENGAN MODEL SUGESTI IMAJINASI MAHASISWA
}

\author{
Dian Nuzulia Armariena \\ (Dosen Universitas PGRI Palembang) \\ Email : diannuzulia@univpgri-palembang.ac.id
}

\begin{abstract}
ABSTRAK
Tujuan dalam penelitian ini untuk mengetahui dan mendeksripsikan pengaruh penulisan puisi bertema lokal budaya dengan model sugesti imajinasi mahasiswa. Populasi dalam penelitian ini adalah mahasiswa semester 4 Program Studi Pendidikan Bahasa dan Sastra Indonesia, yang berjumlah 104 orang. Metode penelitian yang digunakan adalah eksperimen dengan pendekatan deskriptif kuantitatif, desain penelitian one grup pretest-posttest. Untuk mengumpulkan data digunakan teknik tes. Data yang terkumpul dianalisis dengan menggunakan statistik uji t. Keterampilan mahasiswa dalam penulisan puisi tergolong baik, yang ditunjukkan dengan hasil tes akhir belajar mahasiswa lebih besar dari hasil tes awal mahasiswa. Perhitungan uji t menunjukkan bahwa $t_{\text {hitung }} 3,53>2,39 t_{\text {tabel }}$ artinya, hipotesis nol $(\mathrm{Ho})$ ditolak dan hipotesis alternatif $(\mathrm{Ha})$ diterima, sehingga dapat disimpulkan bahwa terdapat pengaruh yang signifikan model sugesti imajinasi terhadap penulisan puisi bertema lokal budaya mahasiswa.
\end{abstract}

Kata Kunci: Penulisan Puisi, Lokal Budaya, Model Sugesti Imajinasi

\section{POETRY WRITING CULTURE LOCAL THEME WITH THE IMAGINATION SUGGESTION MODEL COLLEGER}

\begin{abstract}
The purpose of this study was to find out and describe the influence of poetry writing on local cultural themes with a suggestion model of student imagination. The population in this study were 4th semester students of the Indonesian Language and Literature Education Study Program, totaling 104 people. The research method used was an experiment with a quantitative descriptive approach, one group pretest-posttest research design. To collect data used test techniques. The collected data were analyzed using t test statistics. Students' skills in poetry writing are quite good, which is indicated by the results of the final student learning test greater than the results of the initial student test. The calculation of the $t$ test shows that $t_{\text {counts }} 3,53>2,39 t_{\text {table }}$ means that the null hypothesis $(H o)$ is rejected and the alternative hypothesis ( $\mathrm{Ha}$ ) is accepted, so it can be concluded that there is a significant influence on the imagination suggestion model on poetry with local cultural themes college student.
\end{abstract}

Keywords: Poetry Writing, Local Culture, Imagination Suggestion Model 


\section{A. PENDAHULUAN}

Pembelajaran adalah suatu kombinasi yang tersusun meliputi unsur manusia, material, fasilitas, perlengkapan, dan prosedur yang kondusif agar terjadi interaksi komunikasi belajar mengajar antara guru, peserta didik, dan komponen pembelajaran lainnya. Hosnan (2016:18) menyatakan peranan dosen tidak hanya terbatas sebagai pengajar, tetapi juga sebagai pembimbing, pelatih, pengembang, dan pengelola kegiatan pembelajaran yang dapat memfasilitasi kegiatan belajar mahasiswa dalam mencapai tujuan yang telah ditentukan.

Menulis menurut suatu keterampilan berbahasa yang dipergunakan untuk berkomunikasi secara tidak langsung, tidak secara tatap muka dengan orang lain (Tarigan, 2008:3). Sejalan Armariena menyatakan bahwa kemampuan menulis adalah kemampuan yang bersifat aktif dan produktif di dalam menghasilkan tulisan yang diperoleh melalui proses pembelajaran dan latihan secara terus-menerus. Menulis tidak sama dengan mengarang dan tidak semua orang bisa mengarang, karena untuk menjadi pengarang bakat diperlukan. Tetapi, untuk menulis orang yang mau melatih dirinya, pasti dapat menulis (Armariena, 2017:99).

Hudson (dikutip Aminuddin, 2013:134) menyatakan puisi adalah salah satu cabang sastra yang menggunakan kata-kata sebagai media penyampaian untuk membuahkan ilusi dan imajinasi, seperti halnya lukisan yang menggunakan garis dan warna dalam menggambarkan gagasan pelukisnya.

Dalam proses pembelajaran Bahasa Indonesia khususnya penulisan puisi yang diberikan oleh tenaga pengajar menggunakan model sugesti imajinasi, model tersebut digunakan agar mahasiswa lebih aktif dalam menerima pelajaran yang disampaikan bukan hanya sekedar paham dan mampu melakukan suatu pekerjaan sesuai dengan tujuan pembelajaran yang telah ditetapkan, tetapi juga agar terbentuk sikap-sikap positif. Seperti: kritis, kreatif, inovatif, mandiri, dan terbuka, dengan penggunaan media tersebut membantu dosen memperkaya wawasan mahasiswa. Sehingga pada penggunaan media audio yang akan disampaikan menumbuhkan motivasi dan semangat bagi mahasiswa dalam menerima pelajaran baik secara visual dalam bentuk dua dimensi maupun tiga dimensi yang mempunyai daya tarik yang menarik bagi mahasiswa.

Ayatrohaedi (1986:96--97) menyatakan lokal budaya ialah segenap anasir atau ciri-ciri budaya yang dimiliki oleh sekalian kelompok manusia sebagai pengalaman dari 
hidup yang mereka alami. Kebudayaan suatu masyarakat atau bangsa pada umumnya dapat disebut maju atau berkembang, apabila di dalamnya terdapat anasir kebudayaan baru. Tumbuhnya anasir kebudayaan baru itu bisa terjadi karena dua kemungkinan, yaitu karena ada penemuan atau karena ada pencampuran kebudayaan.

Kondisi kelas yang menyenangkan dapat diwujudkan jika pengajar sebagai figur sentral mampu melakukan inovasi dalam pembelajaran. Penerapan berbagai model pembelajaran merupakan cara dalam melakukan inovasi pembelajaran. Dalam dunia pendidikan suatu model pembelajaran merupakan suatu cara atau alat bagi tenaga pendidik untuk mencapai tujuan pembelajaran (Armariena, 2017:29). Melalui model pembelajaran yang tepat, mahasiswa diharapkan mampu menulis puisi sesuai dengan ejaan yang baik dan benar.

Melihat kondisi demikian, akhirnya peneliti berusaha memberikan solusi alternatif dalam pembelajaran menulis supaya segala permasalahan serta kendala yang terdapat pada mahasiswa maupun dosen dapat teratasi. Penggunaan strategi atau metode yang tepat dapat memperbaiki dan meningkatkan keterampilan mahasiswa dalam menulis. Selain itu, cara mengajar dosen harus menggunakan teknik pembelajaran yang bervariasi secara kreatif. Merujuk pada segala permasalahan di atas, dosen mencari berbagai solusi dalam pembelajaran menulis salah satunya dengan menggunakan model pembelajaran sugesti imajinasi.

Menurut Siswanto (2016:25) model pembelajaran sugesti imajinasi adalah model pembelajaran menulis dengan cara memberikan sugesti lewat lagu untuk merangsang imajinasi siswa. Dalam hal ini, lagu digunakan sebagai pencipta suasana sugesti, stimulus, dan sekaligus menjadi jembatan bagi siswa untuk membayangkan atau menciptakan gambaran dan kejadian berdasarkan tema lagu. Model pembelajaran sugesti imajinasi dapat dijadikan sebagai alternatif model dalam pembelajaran bahasa Indonesia.Model pembelajaran sugesti imajinasi dapat diterapkan dalam pembelajaran menulis.

Menurut Siswanto (2016:27--28) langkah-langkah dalam pembelajaran model sugesti imajinasi terbagi atas beberapa yaitu:

a. Untuk mengukur kemampuan atau pengetahuan yang dimiliki siswa, terutama yang berkaitan langsung dengan keterampilan menulis cerita, Anda wajib memberikan pretes. Soal pretes hendaknya berupa perintah untuk membuat 
karangan atau tulisan. Jenis dan tema karangan harus disesuaikan dengan materi pembelajaran yang akan dilaksanakan. Di samping itu, pretes ini harus memuat semua aspek yang diperlukan dalam menulis.

b. Penting artinya bagi siswa untuk mengetahui tujuan pembelajaran yang akan dijalaninya dengan kompetensi dasar yang harus dikuasai setelah proses pembelajaran dilaksanakan. Jika diibaratkan orang yang sedang menempuh perjalanan, keyakinan akan arah dan tujuan akan membuat orang tersebut tidak setengah hati dalam menempuh perjalanan tersebut. Demikian halnya dengan para siswa. Dengan mengetahui tujuan pembelajaran yang akan dilaksanakan, diharapkan siswa lebih siap dalam mengikuti proses pembelajaran.

c. Prinsip utama apersepsi adalah menjelaskan hubungan antara materi yang akan diajarkan. Anda dapat memberi ulasan singkat tentang materi pembelajaran kosakata, kaidah-kaidah penulisan atau EYD, penyusunan klausa, pembuatan kalimat, penulisan paragraf, dan hal-hal yang berkaitan dengan keterampilan menulis cerita. Kegiatan ini dapat menggugah kembali ingatan siswa terhadap materi-materi yang diperlukan dan sudah dikuasai siswa sebagai syarat dalam pembelajaran menulis cerita.

d. Penjelasan praktik pembelajaran dengan media lagu. Anda menjelaskan kepada siswa enam kegiatan yang akan mereka jalani dalam proses pembelajaran. Keenam kegiatan tersebut adalah a) pemutaran lagu, b) penulisan gagasan yang muncul saat menikmati lagu dan sesudahnya, c) pengendapan atau penelaah dan pengelompokkan gagasan, d) penyusunan outline (kerangka karangan), e) penyusunan karangan, dan f) penilaian kelompok.

e. Anda dan siswa aktif dalam kegiatan pembelajaran. Dalam proses ini Anda harus dapat menjadi motivator dan fasilitator yang baik.

f. Siswa menulis sebuah karangan tanpa didahului dengan mendengarkan lagu. Jenis dan tema karangan tetap sama dengan materi pembelajaran yang baru saja dilaksanakan. Evaluasi terhadap pelaksanaan dan pencapaian tujuan pembelajaran menulis dengan dengan model sugesti imajinasi menjadi tahap ketiga dari kegiatan pembelajaran tersebut. Dalam tahap ini, Anda harus bisa melihat keberhasilan dan kekurangan yang terjadi selama proses berlangsung. Di sisi lain, membandingkan hasil pretes dan pascates dengan membuat grafik perolehan nilai 
dapat menjadi sarana yang cukup efektif untuk melihat presentase pencapaian tujuan pembelajaran yang telah dilaksanakan.

g. Selain tiga tahap yang bersifat teknis, pembelajaran menulis dengan model sugesti imajinasi juga mensyaratkan beberapa hal yang bersifat normatif. Anda harus mempunyai pengetahuan yang luas, terutama tentang lagu-lagu yang sedang digemari para siswa. Hal ini akan sangat membantu Anda dalam memilih lagu sebagai media.

h. Sebagai bentuk tes menulis dengan menggunakan media lagu, Anda bisa memutarkan lagu berjudul "Ibu" yang dinyanyikan Iwan Fals. Kenapa Ibu? Karena semua anak pasti lahir dari seorang ibu, dengan begitu semua siswa bisa mengaitkan langsung apa yang didengar dengan sosok ibu yang dimilikinya.

\section{B. METODE PENELITIAN}

Metode penelitian adalah cara yang digunakan oleh peneliti dalam mengumpulkan data penelitiannya (Arikunto, 2013:203). Berdasarkan pendapat tersebut, maka dalam penelitian ini metode yang akan digunakan adalah metode eksperimen. Metode eksperimen dapat diartikan sebagai metode yang digunakan untuk mencari pengaruh perlakuan terhadap yang lain dalam kondisi yang terkendali. Metode penelitian yang digunakan adalah eksperimen dengan pendekatan deskriptif kuantitatif, desain penelitian one grup pretest-posttest.

"Desain ini melibatkan satu kelompok yang diberi pre-test (01), diberi satu treatment (x) dan diberi post-test (02). Keberhasilan treatment ditentukan dengan membandingkan nilai pre-test dan post-test" (Darmadi, 2011:200). Prosedur penelitian adalah "sebuah titik tolak pemikiran yang akan membantu pelaksanaan kegiatan lebih efektif dan bagaimana cara merancang yang berguna terhadap penelitian. kemudian untuk dianalisis dan mencari perannya sehingga dapat digunakan sebagai kesimpulan yang diharapkan".

Populasi dan sampel, Populasi adalah keseluruhan subjek penelitian (Arikunto, 2013:173). Berdasarkan Pengertian tersebut, populasi dalam penelitian ini adalah keseluruhan mahasiswa semester 4 Program Studi Pendidikan Bahasa dan Sastra Indonesia yang berjumlah 104 siswa. Menurut Arikunto (2013:174) "sampel adalah 
sebagian atau wakil populasi yang diteliti. "Pengambilan sampel dalam penelitian ini dilakukan dengan teknik random sampling didapat kelas 4a.

Teknik pengumpulan data dalam penelitian ini adalah teknik tes. Tes sebagai instrumen pengumpul data adalah serangkaian pertanyaan atau latihan yang digunakan untuk mengukur keterampilan pengetahuan, inteligensi, kemampuan, atau bakat yang dimiliki oleh individu atau kelompok (Riduwan, 2015:57). Tes digunakan untuk memperoleh data mengenai penulisan puisi bertema lokal budaya dengan model sugesti imajinasi. Tes yang digunakan dalam penelitian ini adalah tes penulisan puisi sesuai dengan lokal budaya.

\section{HASIL PENELITIAN DAN PEMBAHASAN}

Dari hasil analisis data penelitian yang telah dilakukan oleh peneliti dengan cara memberikan tes, bahwa mahasiswa yang pembelajaran penulisan puisi menggunakan model pembelajaran sugesti imajinasi mendapatkan hasil yang lebih baik jika dibandingkan dengan hasil belajar mahasiswa yang tidak menggunakan model pembelajaran sugesti imajinasi. Hal ini diketahui dari jumlah mahasiswa yang mencapai nilai di atas 70 sebanyak 28 orang dan di bawah 70 sebanyak 4 orang. Nilai rata-rata mahasiswa adalah 80,90. Sedangkan jumlah mahasiswa yang mencapai nilai di atas 70 sebanyak 12 orang dan jumlah mahasiswa yang tidak mencapai nilai 70 sebanyak 20 orang. Nilai rata-rata mahasiswa adalah 72,93.

Berkaitan dengan pemberian hasil tes terlihat jelas bahwa nilai rata-rata mahasiswa setelah menggunakan model pembelajaran sugesti imajinasi lebih tinggi dibandingkan dengan nilai rata-rata mahasiswa sebelum menggunakan model pembelajaran sugesti imajinasi. Artinya penggunaan model pembelajaran sugesti imajinasi berpengaruh pada penulisan puisi mahasiswa. Dengan adanya penggunaan model pembelajaran sugesti imajinasi, dapat membantu mahasiswa untuk berpikir kreatif dan membantu mahasiswa menemukan cara berpikir baru dalam memecahkan masalah. Dengan demikian, proses belajar-mengajar mampu berlangsung dengan aktif dan menyenangkan sehingga mahasiswa mampu memahami konsep materi yang diberikan dengan mudah. Pada akhirnya jika proses belajar-mengajar dilakukan secara aktif maka akan membantu mahasiswa tersebut dalam mencapai hasil belajar dengan baik sehingga keberhasilan pembelajaran dapat dicapai secara optimal. 
Hasil penelitian tersebut menunjukkan bahwa model pembelajaran sugesti imajinasi lebih efektif dibandingkan tanpa menggunakan model pembelajaran. Hal ini dapat kita ketahui dari hasil penerapan model sugesti imajinasi memperoleh nilai tertinggi 95 dan nilai terendah 65, sedangkan penggunaan metode ceramah memperoleh nilai tertinggi 85 dan nilai terendah 55. Maka hal ini membuktikan bahwa model pembelajaran sugesti imajinasi efektif digunakan dalam peningkatan kemampuan penulisan puisi bertema lokal budaya mahasiswa semester 4 Program Studi Pendidikan Bahasa dan Sastra Indonesia.

Dari hasil uji homogenitas, bahwa sampel yang ada diperoleh dari populasi yang homogen ini dibuktikan bahwa $\left.\mathrm{F}_{\text {hitung }}<\mathrm{F}_{\text {tabel }}=1,05<1,82\right)$ maka $\mathrm{H}_{\mathrm{a}}$ diterima, artinya varians dalam penelitian ini homogen. Untuk uji hipotesis diperoleh $t_{\text {hitung }}=3,53$ pada taraf signifikan 0,05 (5\%) dengan db 64 yaitu 2,39 sehingga $t_{\text {tabel }}<t_{\text {hitung }}=2,39<3,53$

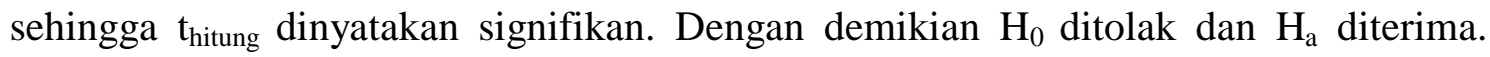
Berdasarkan pernyataan tersebut dapat diketahui bahwa terdapat pengaruh yang signifikan model sugesti imajinasi penulisan puisi bertema lokal budaya semester 4 Program Studi Pendidikan Bahasa dan Sastra Indonesia.

Uji hipotesis yang membuktikan bahwa model pembelajaran sugesti imajinasi berpengaruh dalam penulisan puisi. Hal ini didukung oleh hasil wawancara kepada dosen, yang menyatakan bahwa dengan menggunakan model yang tepat mahasiswa menjadi lebih termotivasi dengan pembelajaran penulisan puisi yang menjadi lebih menarik, penulisan puisi menjadi tidak membosankan, mahasiswa mendapat banyak kesempatan untuk dapat mengembangkan ide puisi sesuai dengan suasana. Siswa pun menjadi lebih mudah untuk memahami pembelajaran dengan baik, sehingga kemampuan mahasiswa dalam menulis bertambah menjadi lebih baik. mahasiswa juga diberikan kesempatan oleh tenaga pendidik untuk dapat menulis puisi berdasarkan background budaya dengan tema yang sesuai dengan kemampuan mahasiswa, sehingga mahasiswa lebih memaksimalkan aktivitas belajarnya secara aktif. 


\section{SIMPULAN}

Berdasarkan hasil penelitian dan pembahasan yang berjudul "Penulisan Puisi Bertema Lokal Budaya dengan Model Sugesti Imajinasi Mahasiswa" maka dapat disimpulkan bahwa model pembelajaran sugesti imajinasi memiliki pengaruh yang signifikan terhadap hasil penulisan puisi mahasiswa semester 4 Program Studi Pendidikan Bahasa dan Sastra Indonesia. Hal ini diketahui dari jumlah mahasiswa yang pembelajaran penulisan puisi menggunakan model pembelajaran sugesti imajinasi yang mencapai nilai di atas 70 sebanyak 28 orang dan di bawah 70 sebanyak 4 orang. Nilai rata-rata mahasiswa adalah 80,90. Sedangkan hasil belajar mahasiswa yang tidak menggunakan model pembelajaran sugesti imajinasi yang mencapai nilai di atas 70 sebanyak 12 orang dan jumlah mahasiswa yang tidak mencapai nilai 70 sebanyak 20 orang. Nilai rata-rata mahasiswa adalah 72,93.

Untuk uji hipotesis diperoleh $\mathrm{t}_{\text {hitung }}=3,53$ pada taraf signifikan $0,05(5 \%)$ dengan $\mathrm{db} 64$ yaitu 2,39 sehingga $t_{\text {tabel }}<\mathrm{t}_{\text {hitung }}=2,39<3,53$ sehingga $\mathrm{t}_{\text {hitung }}$ dinyatakan signifikan. Dengan demikian $\mathrm{H}_{0}$ ditolak dan $\mathrm{H}_{\mathrm{a}}$ diterima. Berdasarkan pernyataan tersebut dapat diketahui bahwa terdapat pengaruh yang signifikan model sugesti imajinasi penulisan puisi bertema lokal budaya semester 4 Program Studi Pendidikan Bahasa dan Sastra Indonesia. 


\section{DAFTAR PUSTAKA}

Aminuddin. 2013. Pengantar Apresiasi Karya Sastra. Bandung: Sinar Baru Algensindo Bandung.

Arikunto, S.2013. Prosedur Penelitian Suatu Pendekatan Praktik. Jakarta: Rineka Cipta.

Armariena, D. N. 2017. Pengaruh Teknik Cerita Pemula Diskusi (Disccusion Starter Story) dalam Menulis Laporan Pengamatan Mahasiswa. Wahana Didaktika: Jurnal Ilmu Kependidikan (Online). Volume 15 Nomor 1:27-37. FKIP Universitas PGRI Palembang.

Armariena, D. N. dan Liza M. 2017. Penulisan Cerpen Berbasis Kearifan Lokal Sumatera Selatan Dengan Metode Image Streaming Dalam Proses Kreatif Mahasiswa. Jurnal PEMBAHSI (Online). Volume 7 Nomor 1:97-103. PPs Universitas PGRI Palembang.

Ayatrohaedi. 1986. Kepribadian Budaya Bangsa. Jakarta: Dunia Pustaka Jaya.

Darmadi, H. 2011. Metode Penelitian Pendidikan. Bandung: Alfabeta.

Hosnan, M. 2016. Pendekatan Saintifik dan Kontekstual dalam Pembelajaran Abad 21. Bogor: Ghalia Indonesia.

Riduwan. 2015. Dasar-Dasar Statistika. Bandung: Alfabeta.

Siswanto, W., dkk. 2016. Model Pembelajaran Menulis Cerita. Bandung: Refika Aditama.

Sudjana, 2005. Penilaian Hasil Proses Belajar Mengajar. Bandung: PT. Remaja Rosdakarya.

Sugiyono. 2013. Metode Penelitian Pendidikan. Bandung: Alfabeta.

Tarigan, H. G. 2008. Menulis Sebagai Suatu Keterampilan Berbahasa. Bandung: Angkasa. 